\title{
Large-scale Investments in Agriculture in India
}

\author{
R. Ramakumar
}

Abstract Public investment in agriculture has significant poverty-reducing effects. This article attempts to
analyse trends in agricultural investments in India between the 1950 s and the 2000 s. It argues that public
investment and expenditure on agriculture in India have grown only slowly and have not decisively increased
even after more than 60 years of independence. While public capital formation and expenditure do show a
moderate rise in the 2000 s, a revival of India's agricultural growth requires a far greater thrust to public
spending. Major and medium irrigation projects require special attention, as irrigation is instrumental not
just in raising yields, but also the number of days of employment for labourers. Increasing public investment
in agricultural research and extension is central to bridging the yield gap that persists. Formal credit flows to
agriculture have to specifically target small and marginal farmers, and emphasis should move away from
generating agricultural growth by channelling credit to agri-business firms and corporate players in
agriculture. If India's second green revolution has to contribute to an accelerated reduction of poverty,
hunger and malnourishment, it undoubtedly has to be a state-led project.

\section{Introduction}

Agricultural growth is central to any strategy of reducing poverty, hunger and malnourishment. The centrality of the role of government in driving agricultural growth is well argued in the literature. The phenomenon of 'market failures' has come to be recognised almost universally (Stiglitz 1996). In developing countries, given the incompleteness, and often absence, of rural markets in a large number of spheres and the pervasiveness of information asymmetry, the role of government in agriculture becomes even more crucial. Specific forms of public expenditure have direct and indirect impacts on agricultural growth.

Public expenditure on agriculture has a significant impact on both agricultural growth and poverty reduction. According to Fan, Hazell and Thorat (2000) who examined Indian data between 1970 and 1993, government spending on productivity-enhancing investments, such as rural infrastructure, irrigation and agricultural research, have significantly contributed to growths in agricultural productivity as well as rural poverty reduction (see also Sen 1997). Fan et al. (2000) further found that public spending on rural roads and agricultural research had the largest impact on agricultural productivity and rural poverty reduction, apart from investments in education and irrigation.

This article attempts to describe the trajectory of agricultural investments in India between the 1950s and the 2000s. It argues that public investment and expenditure on agriculture in India has grown only slowly and has not decisively increased even after more than 60 years of independence. While public capital formation and expenditure does show moderate rise in the 2000s, a revival of India's agricultural growth requires a far greater thrust to public spending.

When India attained independence from colonial rule in 1947, its agriculture was facing a crisis of stagnation. India had an increasingly lopsided agricultural economy, marked by low, and at times declining, crop yields, low shares of irrigated area, large amounts of cultivable land left fallow, a deterioration of soil quality and the use of poor-quality seeds and poorly yielding livestock (Nanavati and Anjaria 1965). In the 50 years that preceded independence, aggregate foodgrain output in India had grown at just 


\begin{tabular}{|c|c|c|c|}
\hline \multirow[t]{2}{*}{ Period/year } & \multicolumn{3}{|c|}{ GFCF in agriculture as a share of agricultural GDP } \\
\hline & Public sector & Private sector & Total GFCF \\
\hline $1950 / 51$ to $1954 / 55$ & - & - & 4.2 \\
\hline $1955 / 56$ to $1959 / 60$ & - & - & 5.3 \\
\hline $1960 / 61$ to $1964 / 65$ & 2.0 & 2.9 & 5.0 \\
\hline $1965 / 66$ to $1969 / 70$ & 1.8 & 3.5 & 5.4 \\
\hline $1970 / 71$ to $1974 / 75$ & 2.2 & 4.0 & 6.2 \\
\hline $1975 / 76$ to $1979 / 80$ & 3.6 & 6.1 & 9.7 \\
\hline $1980 / 81$ to $1984 / 85$ & 3.7 & 4.6 & 8.5 \\
\hline $1985 / 86$ to $1989 / 90$ & 3.1 & 5.0 & 8.2 \\
\hline $1990 / 91$ to $1994 / 95$ & 2.2 & 5.4 & 7.6 \\
\hline $1995 / 96$ to $1999 / 2000$ & 1.9 & 6.1 & 8.1 \\
\hline 2000/01 & 1.8 & 9.0 & 10.8 \\
\hline 2001/02 & 2.1 & 11.1 & 13.1 \\
\hline 2002/03 & 2.0 & 11.7 & 13.6 \\
\hline 2003/04 & 2.3 & 9.7 & 12.0 \\
\hline 2004/05 & 2.9 & 10.6 & 13.5 \\
\hline 2005/06 & 3.3 & 10.9 & 14.1 \\
\hline 2006/07 & 3.5 & 10.2 & 13.8 \\
\hline 2007/08 & 3.3 & 11.3 & 14.6 \\
\hline 2008/09 & 3.2 & 14.3 & 17.5 \\
\hline 2009/10 & 3.2 & 17.3 & 16.8 \\
\hline
\end{tabular}

Source Computed from CSO reports.

0.1 per cent per annum (Blyn 1966). Thus, at the time of independence, India needed to substantially step up public investment in agriculture. Irrigation and flood control demanded priority attention from the government, and hence, capital expenditure on major and medium irrigation projects needed to be significantly increased. Investments in agricultural research and extension and rural infrastructure, which were in the nature of public goods, also had to be increased. To incentivise the adoption of new technologies, cultivators also needed access to affordable credit. This article tracks trends in these candidate investments.

The most immediate source of information on agricultural investment in India are the data on gross fixed capital formation (GFCF) from the Central Statistical Organisation (CSO). Most of the early studies on agricultural investment used data from the CSO as the basis of analysis (see Shetty 1990). However, in the 1990s and after, many scholars argued that data provided by the CSO do not fully capture all the components of agricultural investment (Thulasamma 2003; Sawant et al. 2002; Gulati and Bathla 2001; Chand 2000; Mishra and Chand 1995). First, CSO data did not adequately capture public expenditure on rural roads, rural electrification and provision of market infrastructure in rural areas. Secondly, CSO data also did not capture the revenue expenditure component of budgetary spending on agriculture; as is well known, revenue expenditures of the government may include significant capital components. 


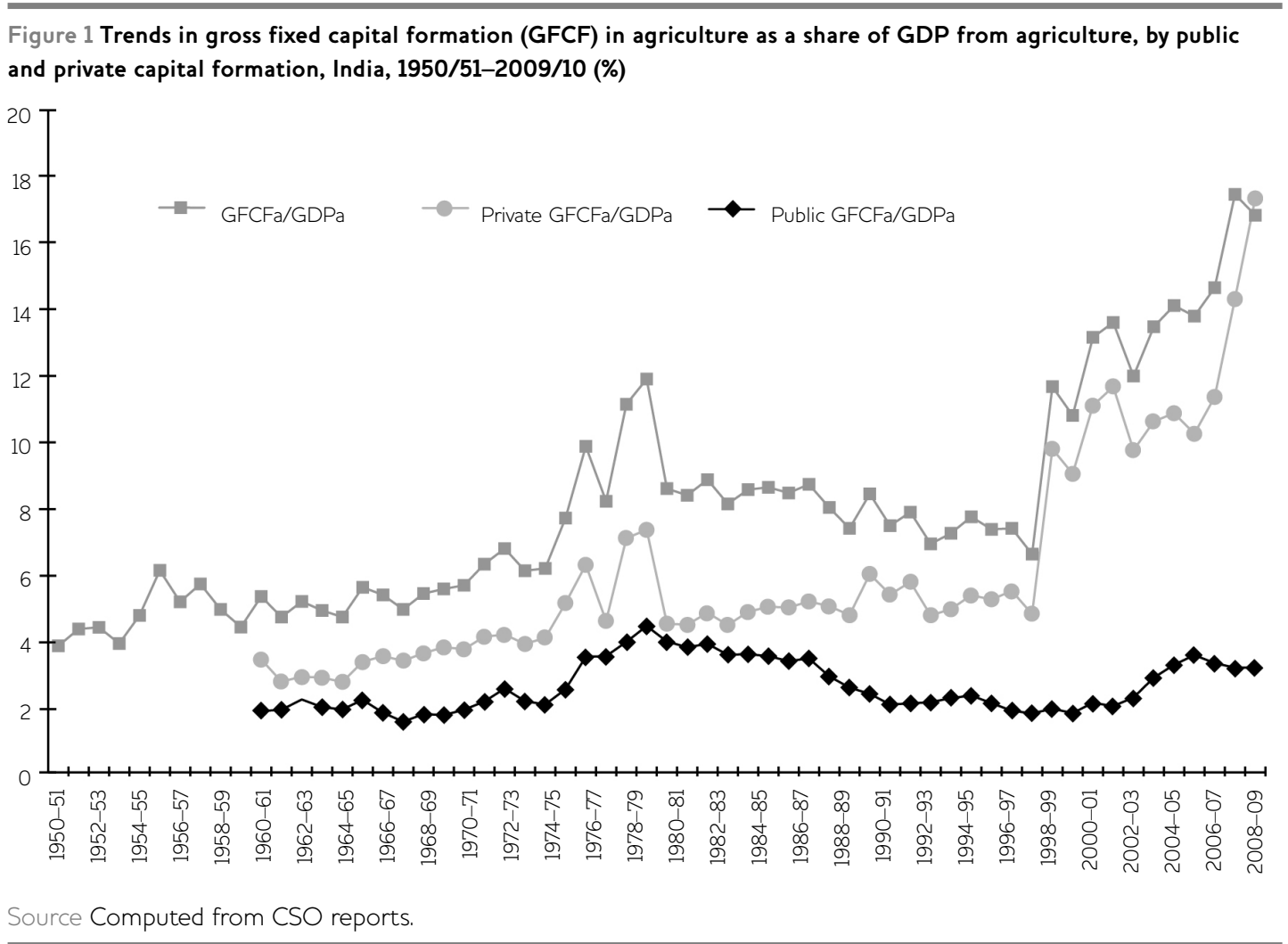

Given these two inadequacies of CSO data, I have in this article used data on investment and expenditure from different official sources separately and analysed trends; all these are channels through which public money flows into agricultural investment. They include: (a) public capital formation in agriculture from the CSO; (b) public expenditure on agriculture from the annual government budgets; and (c) supply of credit to agriculture from public banks. Through the article, a long-period analysis is attempted, even if greater emphasis is given to the trends in the 1990 s and $2000 \mathrm{~s}$.

The article is divided into five sections. The second section analyses the trends in fixed capital formation in agriculture in India. The third section looks at trends in budgetary expenditure of the Gentral and State Governments in India. The fourth section deals with the trends in credit flow to agriculture from public banks in India. The final section gives the conclusions.

\section{Public and private gross fixed capital formation in agriculture}

Gross capital formation (GCF) in the CSO data includes both gross fixed capital formation
(GFCF - acquisition of fixed assets) as well as accumulation of stocks. In this section, I have used data on GFCF alone to understand trends in capital formation. In other words, I am looking at that part of the nation's total expenditure on agriculture that is not consumed but added to the nation's fixed tangible assets. In India, GFCF in agriculture primarily includes investment in major and medium irrigation projects.

First, GFGF in agriculture formed less than 6 per cent of the agricultural GDP in the 1950s and 1960s (Table 1 and Figure 1). In the 1970s, the share of agricultural GFCF in agricultural GDP grew sharply and reached its peak value of 12 per cent in 1979/80. The growth of agricultural GFCF began to decline in the second half of the 1980s. The 1990s witnessed a sharp fall in the share of agricultural GFCF to agricultural GDP; in 1998/99, this share was almost half of that in 1979/80. In the 2000s, the share began to rise, reaching 14 per cent of the agricultural GDP in 2005/06 and 17 per cent of the agricultural GDP in 2009/10. Thus, there was a revival of GFCF in agriculture in the 2000s.

Secondly, public investment in agriculture, as a share of agricultural GDP, rose till the late 
1970 s, began to decline from the early 1980 s and continued to decline in the 1990s up to 2004/05. After 2004/05, there was a moderate improvement in public investment, although this began to fall again after 2006/07. In 2009-10, the share of public GFCF in agricultural GDP stood at 3.2 per cent, which was still lower than the corresponding share for the early 1980s.

Thirdly, private investment in agriculture rose alongside public investment till the late 1970s, stagnated in the $1980 \mathrm{~s}$, increased moderately in the 1990s and increased rapidly in the 2000s. While the rise in private investment in the 1980s and 1990s was insufficient to compensate for the fall in public investment, the rise of total investment in the 2000s was aided significantly by the growth in private investment.

One of the characteristic features of investment in Indian agriculture has been the complementarity between public and private investment (Dhawan 1998; Rao 1998; Storm 1993; Shetty 1990). In a growing economy, public investment induces or 'crowds in' private investment by farmers. Thus, typically, public investment in irrigation leads to complementary private investment in constructing field channels and bunds, drainage and levelling of fields (see Mishra and Chand 1995). Similarly, public investment in rural infrastructure, such as electrification, can help mobilise significant private finance in irrigation investment (Rawal 1999). Even if a direct causal relationship between public and private investment is weak, as Mishra and Chand (1995: A70) argue, complementarity 'represents a relationship of being and acting together to produce an outcome, which would not be possible in the absence of the complement'.

In the 1990s and 2000s, however, the shift in the relationship of complementarity was unmistakable. Private investment grew even in the absence of preceding public investment. It may be argued, as I do below, that the autonomous nature that private investment attained in the 1990s and after may well be a response to a sustained stagnation in public investment, particularly in surface irrigation.

Data from the All India Debt and Investment Surveys (AIDIS) of 1992 and 2003 show new patterns in the trends and composition of private investment in agriculture. First, the increase in private investment in the 1990 s and early 2000 s was confined to a smaller section of cultivators than in the 1980s. The share of rural households that reported any fixed capital expenditure in farm business fell from 8.5 per cent in 1992 to 6.8 per cent in 2003 . The corresponding share for rural cultivator households fell from 11.9 per cent in 1992 to 10.3 per cent in 2003. Further, for all rural households, the share of fixed capital expenditure in farm business in the total fixed capital expenditure fell from 32.8 per cent in 1992 to 21.8 per cent in 2003.

Secondly, even while the share of cultivators reporting fixed capital expenditure was falling, cultivators were according more priority to certain specific forms of investment. Within private fixed capital formation, the share spent on construction of wells and other irrigation sources increased from 31.8 per cent in 1992 to 38.4 per cent in 2003. Similarly, the share spent on farmhouses increased from 4.2 per cent in 1992 to 9.6 per cent in 2003. On the other hand, the share spent on improvement/reclamation of land fell sharply from 14.3 per cent in 1992 to 6.9 per cent in 2003.

Thus, even in the absence of public investment in surface irrigation, there has been autonomous investment by farmers in the exploitation of groundwater irrigation. However, sustained exploitation of groundwater, in the absence of investment in surface irrigation, has its limits. According to an assessment of groundwater resources in 5,723 blocks of India by the Ministry of Water Resources, 15 per cent were classified as 'over-exploited', 4 per cent as 'critical' and 10 per cent as 'semi-critical' (GoI 2011). The share of over-exploited blocks in an earlier survey in 1995 was lower at 4 per cent.

Unregulated expansion of groundwater irrigation, without allowing for sustainable recharge of wells from surface sources, could have adverse environmental implications: stagnation of yields, loss of soil fertility, acute problems of salinity, increase in pumping depths, rise in pumping costs, reduction of well yields, and acute scarcity of groundwater in summer months (Planning Commission 2007).

In sum, a few points may be made. First, there appears to be a clear and continuing role for public investment in surface irrigation in India. Secondly, 
Figure 2 Expenditure on agriculture and allied activities (AAA) as a share of GDP, total expenditures, and total development expenditures, Central Government, revenue and capital, 1974/75-2009/10 (\%)

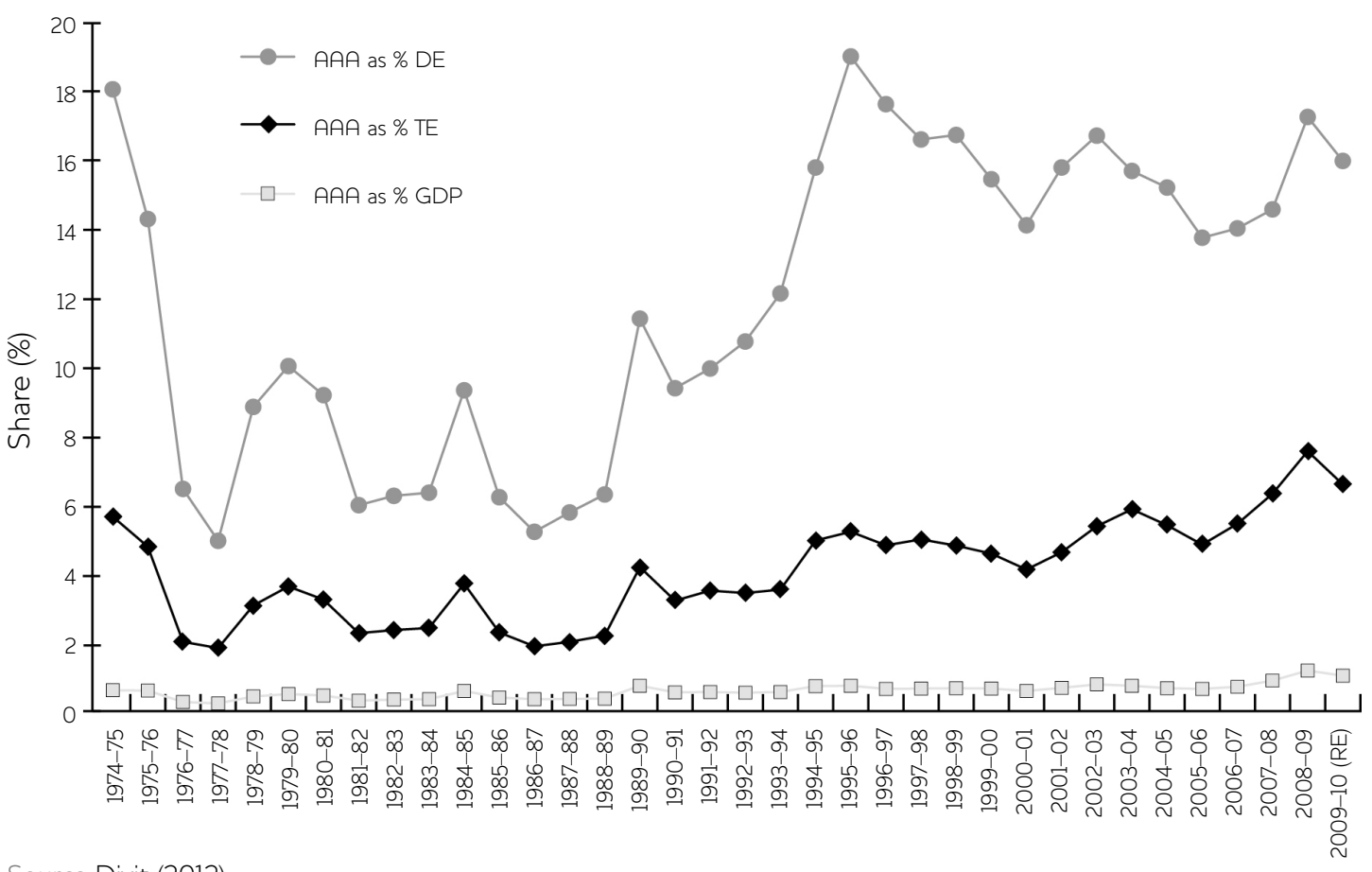

Source Dixit (2012).

public investment appears crucial in land augmentation, especially in rainfed and backward regions, where private investment has not been forthcoming (on this, see Rao 1998). Thirdly, in areas where groundwater scarcity has had acute negative externalities, expenditures to undo the environmental losses also would have to be borne by the government. All these demand a significant step-up of public investment in agriculture in the recent future. The environmental implications of depending singularly on private sector investment in irrigation appear clear.

During the 11 th Five Year Plan period of 2007-12, while the overall investment rate in the economy as a share of GDP was 36 per cent, the corresponding share within agriculture was only 21 per cent. The backlog in agricultural investment appears evident from these figures and can act as a benchmark to formulate annual targets for raising public sector investment.

\section{Public expenditure on agriculture}

3.1 Public expenditure on agriculture and allied activities

Apart from investing in capital formation in agriculture, the government also sets apart budgetary resources on the revenue and capital accounts for agriculture and allied sectors. All of this expenditure is not captured in the data on GFCF in agriculture from the CSO. According to Chand (2000), if the figures for expenditure on selected items from the finance accounts of Central and State Governments are taken into account, the extent of underestimation in the C.SO series may be about 52 per cent. In this section, I shall separately deal with the trends in budgetary expenditure of the Central and State Governments. The data used come from the official reports of the Ministry of Finance and the Reserve Bank of India (RBI).

As a share of total GDP, the share of expenditure by the Central Government on agriculture and allied activities remained largely stagnant between 1974/75 and 2009/10. In fact, the expenditure on agriculture and allied activities never exceeded 8 per cent of the total expenditure for any year after 1974/75 (see Figure 2). The share of expenditure on agriculture was about 6 per cent in the mid-1970s; this fell and stabilised at about 2 per cent between 1976/77 and 1988/89. By 2000/01, the share of expenditure on agriculture had risen to about 6 per cent. Even though there was a sharp rise in the expenditure 
Figure 3 Expenditure on agriculture and allied activities (AAA) as a share of GDP and total expenditure, all State Governments, revenue and capital, 1974/75-2009/10 (\%)

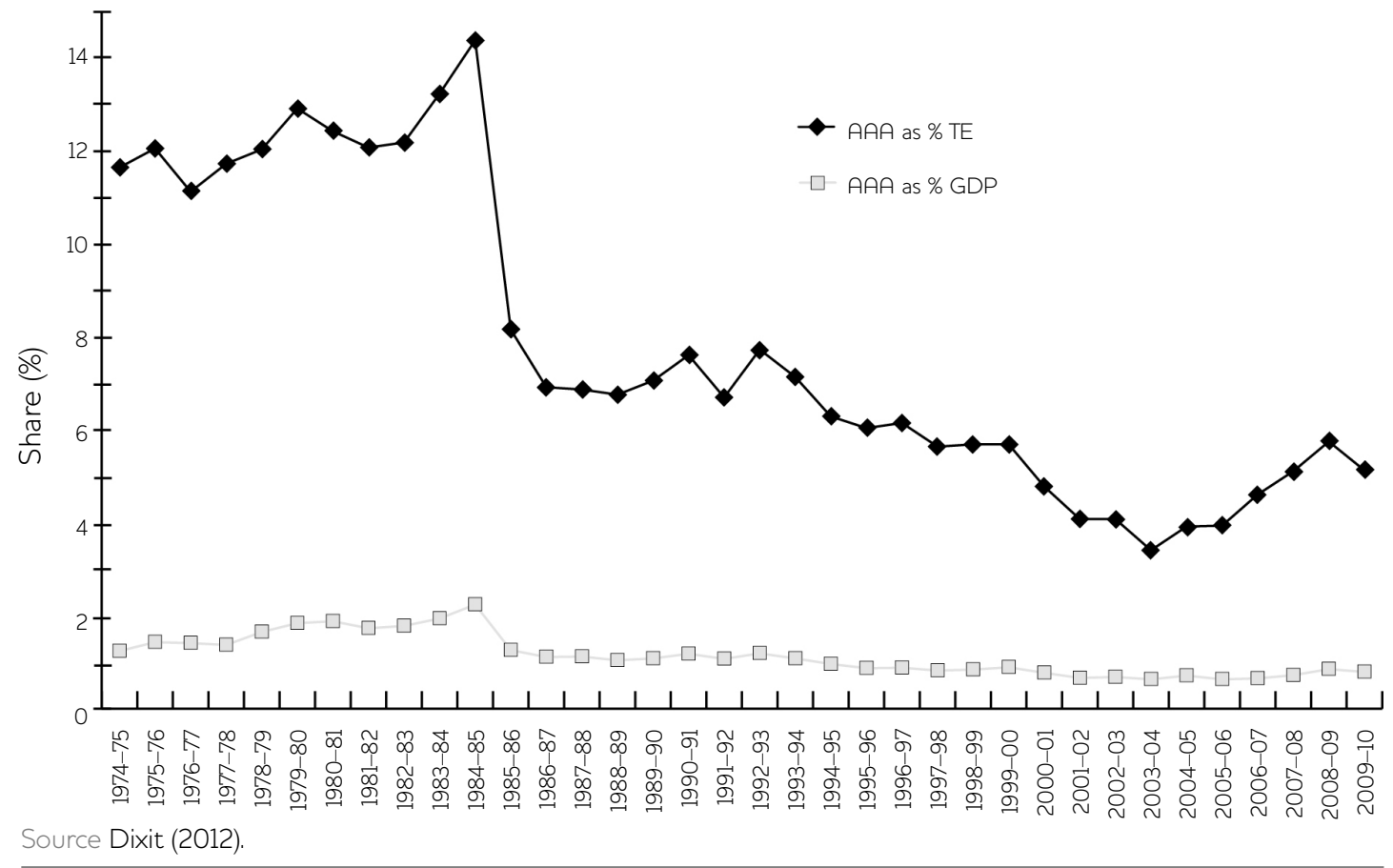

on agriculture in the second half of the 2000 s, the share of expenditure stood a little above 6 per cent even in 2009/10, which was almost identical to the corresponding share in $1974 / 75$.

What is more distressing is that after 1995/96, the share of expenditure on agriculture as a share of 'developmental expenditures' declined consistently right up to 2009/10. In Indian budgets, developmental expenditures are classified so by fiat; they represent Plan expenditures that are considered to directly contribute to economic development. 'Non-developmental expenditures', on the other hand, represent those forms of spending incurred on the maintenance of general services. Given that such a classification is primarily a form of accounting, it would be wrong to mechanically privilege developmental expenditures over non-developmental expenditures. Yet the fact remains that the share of expenditure that would directly contribute to agricultural development in the Central Government budgets has declined since 1995/96.

In the budgets of State Governments, the share of expenditure on agriculture and allied activities in the GDP declined between the mid1980s and 2009/10 (Figure 3). As a share of the total expenditure, the share of expenditure on agriculture and allied activities declined more sharply in the same period. In 1984/85, about 14 per cent of the total expenditure of the State Governments was earmarked for agriculture and allied activities; in 2009/10 the corresponding share fell to about 5 per cent. As the total expenditure of the State Governments is higher than that of the Central Government, the total expenditure on agriculture and allied and activities as a share of total expenditure is also likely to have fallen in the 1990s and 2000s.

The decline of expenditures on agriculture at central and state levels in the long run has had ominous impacts on agricultural growth. In the 1990s and since, most of the declines in expenditures have taken place in agricultural research and education, agricultural extension, storage and warehousing and soil and water conservation (Dixit 2012).

\subsection{Public expenditure on research and extension}

There was a significant slowdown of public expenditure in two specific sectors within agriculture: research and extension. From the mid-1960s onwards, agricultural research and extension have been sectors where the Indian 


\begin{tabular}{|c|c|c|}
\hline \multirow[t]{2}{*}{ Period } & \multicolumn{2}{|c|}{ Growth rate of public expenditure } \\
\hline & Research and education & Extension and training \\
\hline 1960s & 6.5 & 10.7 \\
\hline 1970s & 9.5 & -0.1 \\
\hline 1980s* & 6.3 & 7.0 \\
\hline 1990-2005 & 4.8 & 2.0 \\
\hline
\end{tabular}

*For Extension and training, the figure for the 1980s is as for 1980-94.

Source Balakrishnan et al. (2008).

government invested heavily and where private investment was not significant. Extensive public support was encouraged, as these were considered to be 'public goods'. As public goods are prone to market failures, it was considered necessary that the state should step in and invest. According to Vaidyanathan (2000), 'the widespread nation-wide network of specialized research stations under the ICAR and the agricultural universities, working with and through the National Extension Service, have contributed significantly to raising productivity by developing and diffusing better varieties and practices'.

From the late 1980 s and early 1990 s, there were major shifts in the official policy on agricultural research and extension (see Ramakumar 2010). The new policies focused on encouraging private sector investment in research and extension. As per the new industrial policy of 1986, seed and biotechnology firms were reclassified as core industries, with the result that the entry of large firms became easier. As per the new Seed Policy in 1988, the domestic seed industry was further liberalised with considerable incentives offered to private players to enter into seed production. After 1991, 100 per cent foreign equity was allowed in the seed industry and seed imports were allowed for research purposes under the Open General License (OGL). The introduction of Intellectual Property Rights (IPRs) in plant breeding was an important component of the World Trade Organization (WTO) agreement in 1995. Similarly, according to the National Agriculture Policy of 2000, 'the government will endeavour to move towards a regime of financial sustainability of extension services through effecting... a more realistic cost recovery of extension services and inputs'. In this view, the government was to withdraw subsidies on extension services, so that it can compete with private sector providers of extension services.

In the 1990s and 2000s, there was a decline in the rate of growth of public spending on agricultural research and extension compared to earlier decades (Table 2). The growth rate of public spending on agricultural research fell from 6.3 per cent in the 1980 s to 4.8 per cent in the 1990s and 2000s. The corresponding figures for agricultural extension were 7 per cent in the 1980 s and 2 per cent in the 1990s and 2000s. If I consider public spending on research and extension as a share of agricultural GDP, then a slightly different set of results emerges (Table 3). As a share of agricultural GDP, public expenditure on research shows a moderate rise in the 2000s, while public expenditure on extension shows a clear decline.

The share of public investment in agricultural research in agricultural GDP in India has always been lower than the corresponding shares for developed countries. As a share of the agricultural GDP, public spending on agricultural research in India was only 0.52 per cent in 2004-06, as compared to 2-3 per cent in the developed world. In other words, the decline in the growth rate of public spending on agricultural research in the 1990s and 2000s slowed down the process of India's 'catching up' with developed countries. According to a Planning Commission review, the sluggish growth in Indian agriculture in the 1990s was mainly due to 'weakened support systems', and in particular, 'unresponsive agricultural research, nearly broken down extension [and] inadequate seed production, distribution and regulation' (GoI 2005: 197). 


\begin{tabular}{|c|c|c|}
\hline \multirow[t]{2}{*}{ Year/period } & \multicolumn{2}{|c|}{ As a share in agricultural GDP, expenditure } \\
\hline & Research and education & Extension and training \\
\hline 1960-62 & 0.21 & 0.09 \\
\hline 1970-72 & 0.23 & 0.14 \\
\hline 1980-82 & 0.39 & 0.11 \\
\hline 1989-91 & 0.41 & 0.16 \\
\hline 1992-94 & 0.40 & 0.15 \\
\hline 1995-97 & 0.38 & 0.14 \\
\hline 1998-00 & 0.44 & 0.15 \\
\hline 2001-03 & 0.52 & 0.13 \\
\hline 2004-06 & 0.52 & 0.13 \\
\hline
\end{tabular}

Source Balakrishnan et al. (2008).

Concurrent to the weakening of the public sector, there has been an increasing control of private firms over agricultural research and extension. Private sector research and extension has never in the developing world been seen as a substitute for the public sector. Pardey and Beintema (2001) noted that private research across the world covered only a 'small sub-set of the needs of the poor'. Technologies developed by the private sector were mainly suited to 'capital-intensive forms of commercial agriculture with high valueadded aspects off the farm'. Private sector research has focused mainly on the development of herbicides, insecticides and technologies related to food storage, transport and processing technologies (see also Alston et al. 2000). In India too, private sector agricultural research is confined to a few crops, such as maize, sunflower, cotton, pearl millet, oil seeds and sorghum, where the expected profit levels are high. In most foodgrain crops like paddy and wheat, private agencies have had very little presence.

It is clear that along with a reversal of the decline in public investment in capital formation in agriculture, a reversal of the slowdown in public investment in research and extension are also critical factors associated with the revival of agricultural growth in India.

\section{Credit to agriculture}

Credit supply is an important determinant of private investment in agriculture (see Shetty
1990). Since the nationalisation of commercial banks in 1969, India had strongly pursued a policy of social and development banking in the rural areas. As a result, formal institutions of credit provision, mainly commercial banks, emerged as important sources of finance to agriculture, displacing usurious moneylenders and landlords. The policy of social and development banking was a supply-led policy; it aimed at augmenting the supply of credit to rural areas, and that too at an affordable interest rate (Shetty 2006; Chavan 2005).

There is little quarrel among economists on the effect that the increased flow of credit after 1969 had on agricultural growth in India. Increased availability of credit from public banks helped small and marginal farmers adopt costlier new technologies and farming practices, which were a part of the green revolution strategy.

Yet, in the early 1990s, the policy of social and development banking was criticised by the proponents of financial liberalisation. The Committee on the Financial System (Narasimham Committee) argued that banks should function on a commercial basis, and profitability should be the prime concern in their activities (RBI 1991). It was also argued that banks should be given a free hand to charge rates of interest as administering interest rates would lead to financial repression. Banks were also to be permitted to close rural branches, in the name of rationalisation of branch 


\begin{tabular}{|c|c|c|c|}
\hline \multirow[t]{2}{*}{ Year } & \multicolumn{3}{|c|}{ Share in total agricultural credit (\%) } \\
\hline & Direct finance & Indirect finance & Total \\
\hline 1985 & 83.2 & 16.8 & 100.0 \\
\hline 1990 & 86.8 & 13.2 & 100.0 \\
\hline 2000 & 84.5 & 15.5 & 100.0 \\
\hline 2005 & 76.1 & 23.9 & 100.0 \\
\hline 2006 & 72.1 & 27.9 & 100.0 \\
\hline 2007 & 74.5 & 25.5 & 100.0 \\
\hline 2008 & 77.5 & 22.5 & 100.0 \\
\hline 2009 & 77.1 & 22.9 & 100.0 \\
\hline 2010 & 76.1 & 23.9 & 100.0 \\
\hline
\end{tabular}

Source 'Basic Statistical Returns', Reserve Bank of India, various issues.

networks. The recommendations of the Narasimham Committee, except a few, were implemented to a large extent in the 1990s.

The period of financial liberalisation after 1991 has been a period of reversal of the achievements of social and development banking. A consequence of the squeeze on formal credit in the 1990s was a sharp fall in the growth of credit flow to agriculture and a resurgence, to different degrees across India, of the informal credit sector, particularly moneylenders (for details, see Ghavan 2007, 2005; Shetty 2006; Ramachandran and Swaminathan 2005).

The slowdown in agricultural credit in the 1990s was reversed in the period after 2000, and particularly after 2004/05. After growing modestly till the early 2000 s, the overall flow of credit to agriculture rose rapidly after 2004/05 (Ramakumar and Chavan 2007). In fact, the increase in the growth rate of agricultural credit in the 2000s was so significant that the level of credit reached in 2010 was higher than what it would have been if credit had grown in the 1990s and 2000 s at the growth rate of the 1980s.

Notwithstanding the revival of agricultural credit in the 2000s, two factors raise serious concern over its potential to drive a revival of agricultural growth. First, though availability of credit may drive private investment, credit need not always be employed productively on the farm. The productive use of individual credit continues to be constrained by the absence of public investment, particularly in irrigation and rural infrastructure.

Secondly, only a part of the additional supply of agricultural credit in the 2000s has been directed to cultivators. As Table 4 shows, in 1990 about 87 per cent of agricultural credit was provided as direct finance (given directly to cultivators).

However, the share of direct finance declined after 1990 , and in 2010, only about 76 per cent of total agricultural credit was direct finance. In other words, about one-fourth of the total agricultural credit in 2010 was in the nature of indirect finance (which does not go directly to cultivators, but to input dealers, fertiliser dealers and so on).

In the phase of rising indirect finance, the supply of agricultural credit has assumed a totally different role - that of financing new forms of commercial, export-oriented and capital-intensive agriculture, including by corporate houses. Such a shift has been facilitated by a series of definitional changes on what constitutes credit in agriculture (Ramakumar and Chavan 2007). For instance, from 2007 onwards, two-thirds of loans given to corporates, partnership firms and institutions for agricultural and allied activities in excess of Rs 1 crore per borrower were considered as indirect finance to agriculture by the RBI; the remaining third was treated as direct finance. 


\begin{tabular}{|c|c|c|c|c|}
\hline \multirow{2}{*}{$\begin{array}{l}\text { Credit limit size } \\
\text { class of loans (Rs) }\end{array}$} & \multicolumn{4}{|c|}{ Share of amount outstanding in total amount outstanding (\%) } \\
\hline & 1990 & 2000 & 2005 & 2010 \\
\hline Less than 2 lakh & 82.6 & 67.6 & 51.9 & 44.3 \\
\hline 2 lakh to 10 lakh & 4.3 & 11.7 & 17.9 & 22.6 \\
\hline 10 lakh to 1 crore & 7.6 & 6.6 & 6.4 & 6.4 \\
\hline 1 crore to 10 crore & 4.2 & 6.7 & 8.0 & 6.3 \\
\hline 10 crore to 25 crore & \multirow[t]{2}{*}{1.3} & 1.7 & 3.3 & 2.7 \\
\hline Above 25 crore & & 5.7 & 12.6 & 17.7 \\
\hline Total advances & \multicolumn{2}{|l|}{100.0} & 100.0 & 100.0 \\
\hline
\end{tabular}

Note US $\$ 1=$ Rs 51.5 .

Source 'Basic Statistical Returns', Reserve Bank of India, various issues.

Due to such changes in definitions, the nature of agricultural credit itself has undergone major changes between the 1990s and 2000s (see Table 5). A loan above the size of Rs 2 lakh (roughly US $\$ 3,880$ ) can hardly be termed as a loan to an Indian farmer. Yet, in 2010, loans above the size of Rs 2 lakh constituted about
56 per cent of all agricultural credit. More importantly, loans of size above Rs 25 crore (roughly US $\$ 48,543,690$ ) constituted about 18 per cent of all agricultural credit. The enormous growth of agricultural credit in the loan size classes of above Rs 2 lakh is indicative of a huge flow of credit into sectors newly added into the

Figure 4 Trends in gross capital formation in agriculture and allied sectors and agricultural credit, at current prices, India, 1993/94-2010/11

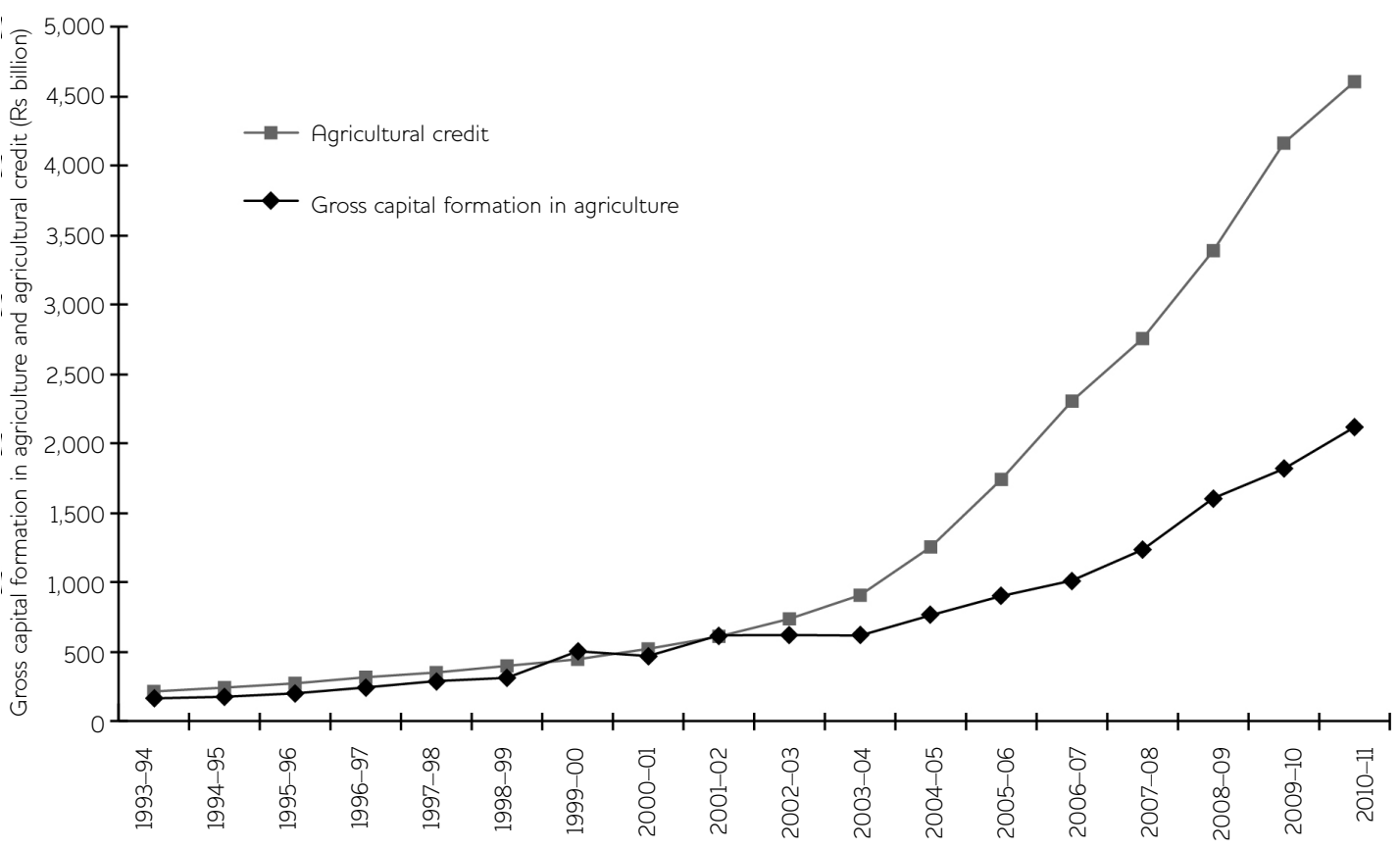

Source Compiled from various $\mathrm{CSO}$ and RBI reports. 
ambit of agricultural credit, such as loans to corporates and partnership firms. In other words, it is unlikely that the increase in agricultural credit in the 2000s has aided private investment by small and marginal farmers.

The changes in the nature of agricultural credit in the 2000s also led to a growing disconnect between credit and investment in agriculture. As Figure 4 shows, till 2001/02, the difference between agricultural credit and gross capital formation in agriculture was almost insignificant. Credit and capital formation were roughly at similar levels, and they moved together every year. However, after 2001/02, trends in credit and capital formation began to diverge. From 2002/03 onwards, agricultural credit grew rapidly compared to capital formation in agriculture, and the difference between the amounts of agricultural credit and agricultural capital formation grew. In other words, only an increasingly smaller portion of credit supplied to agriculture was transformed into capital investment in agriculture in the 2000s.

\section{Concluding points}

Public investment in agriculture in India has been shown to have powerful poverty-reducing

\section{References}

Alston, J.M.; Marra, M.G.; Pardey, P.G. and Wyatt, T.J. (2000) A Meta Analysis of Rates of Return to Agricultural RED: Ex Pede Herculem?, Research Report 113, Washington DC: International Food Policy Research Institute

Balakrishnan, P.; Golait, R. and Kumar, P. (2008) Agricultural Growth in India since 1991, Study 27, Mumbai: Development Study Group, Reserve Bank of India

Blyn, George (1966) Agricultural Trends in India; 1891-1947: Output, Availability and Productivity, Philadelphia PA: Pennsylvania University Press

Chand, Ramesh (2000) Emerging Trends and Regional Variations in Agricultural Investments and their Implications for Growth and Equity, Policy Paper, New Delhi: National Centre for Agricultural Economics and Policy Research

Chavan, Pallavi (2007) 'Access to Bank Credit: Implications for Rural Dalit Households', Economic and Political Weekly 42.31: 3219-23

Chavan, Pallavi (2005) 'How "Inclusive" are Banks under Financial Liberalisation?', Economic and Political Weekly 40.43: 4647-49

Chavan, Pallavi (2002) 'Some Features of Rural Credit in India: A Study after the Period of Bank effects. Yet public investment and expenditure of the Indian government in agriculture have grown slowly, and have not decisively increased over the 60 years of its independence. While public capital formation and expenditure does show a moderate rise in the $2000 \mathrm{~s}$, it is clear that a revival of India's agricultural growth requires a far greater thrust to public spending. Overall agricultural investment needs to be raised to at least 36 per cent of the agricultural GDP, as compared to the current levels of about 21 per cent. Major and medium irrigation projects require special attention, as irrigation is instrumental not just in raising yields, but also in increasing the number of days of employment for labourers. Raising public investment in agricultural research and extension is central to bridging the yield gap that persists. Formal credit flow to agriculture has to specifically target small and marginal farmers, and emphasis should move away from generating agricultural growth by channelling credit to agri-business firms and corporate players in agriculture. In sum, if India's second green revolution has to contribute to an accelerated reduction of poverty, hunger and malnourishment, it undoubtedly has to be a state-led project.

Nationalisation', MPhil thesis, Indira Gandhi Institute of Development Research, Mumbai Dhawan, B.D. (1998) Studies in Agricultural Investments and Rural Savings, New Delhi: Commonwealth Publishers

Dixit, Aditi (2012) 'Levels and Composition of Public Expenditures in India: 1960-61 to 2009-10', MPhil thesis, Tata Institute of Social Sciences, Mumbai

Fan, Shenggen; Hazell, Peter and Thorat, Sukhadeo (2000) 'Government Spending, Growth and Poverty in Rural India', American Journal of Agricultural Economics 82.4: 1038-51

GoI (Government of India) (2011) Annual Report 2009-10, New Delhi: Ministry of Water Resources

GoI (Government of India) (2005) Agriculture and Food Security, Mid-term Review of the Tenth Five Year Plan, Part II, chapter 5, New Delhi: Planning Commission

Gulati, Ashok and Bathla, Seema (2001) 'Capital Formation in Indian Agriculture: Revisiting the Debate', Economic and Political Weekly 36.20: 1697-1708

Mishra, S.N. and Chand, Ramesh (1995) 'Public and Private Capital Formation in Indian 
Agriculture: Comments on the

Complementarity Hypothesis and Others', Economic and Political Weekly 30.25: A65-A79

Nanavati, M.B and Anjaria, J.J. (1965) [1947] The Indian Rural Problem, Mumbai: Indian Society of Agricultural Eonomics

Pardey, Philip G. and Beintema, Nienke M. (2001) Slow Magic: Agricultural R \& D after Mendel, Washington DC: International Food Policy Research Institute

Planning Commission (2007) Report of the Expert Group on Groundwater Management and Ownership, Chair: Kirit S. Parikh, New Delhi: Planning Commission

Ramachandran, V.K. and Swaminathan, Madhura (eds) (2005) Financial Liberalisation and Rural Credit in India, New Delhi: Tulika Books

Ramakumar, R. (2010) 'Continuity and Change: Notes on Agriculture in "New India", in Anthony D'Costa (ed.), A New India? Critical Perspectives in the Long Twentieth Century, London: Anthem Press

Ramakumar, R. and Chavan, Pallavi (2007) 'Revival of Agricultural Credit in the 2000s: An Explanation', Economic and Political Weekly 42.52: 57-64

Rao, Mohan J. (1998) 'Food, Agriculture and Reforms: Change and Continuity', Economic and Political Weekly 33.29/30: 1955-60

Rawal, Vikas (1999) 'Irrigation Development in West Bengal: 1977-78 to 1995-96', PhD thesis, Indira Gandhi Institute of Development Research, Mumbai

RBI (Reserve Bank of India) (1991) Report of the Committee on Financial Systems, Chairman: M. Narasimham, Mumbai

Sawant, S.D.; Daptardar, V. and Mhatre, S. (2002) 'Capital Formation and Growth in
Agriculture: Neglected Aspects and Dimensions', Economic and Political Weekly 37.11: 1068-72

Sen, Abhijit (1997) 'Agricultural Growth and Rural Poverty', in G.K. Chaddha and Alakh N. Sharma (eds), Growth, Employment, Poverty Change and Continuity in Rural India, New Delhi: Indian Society of Labour Economics

Shetty, S.L. (2006) 'Policy Responses to the Failure of Formal Banking Institutions to Expand Credit Delivery for Agriculture and Non-farm Informal Sectors: The Ground Reality and Tasks Ahead', revised version of the seminar paper, Monthly Seminar Series on India's Financial Sector, New Delhi, ICRIER, 14 November

Shetty, S.L. (1990) 'Investment in Agriculture: A Brief Review of Recent Trends', Economic and Political Weekly 25.7/8: 389-98

Stiglitz, J.E. (1996) 'The Role of Government in Economic Development', keynote address at the Annual World Bank Conference on Development Economics, reprinted in Bagchi, Amaresh (ed.) Readings in Public Finance, New Delhi: Oxford University Press

Storm, Servaas (1993) Macroeconomic Considerations in the Choice of an Agricultural Policy: A Study into Sectoral Interdependence with Reference to India, Aldershot: Avebury Press

Thulasamma, L. (2003) 'Investment in Agriculture: Trends and Issues', paper presented in the All-India Conference on Agriculture and Rural Society in Contemporary India, Barddhaman, 17-20 December

Vaidyanathan, A. (2000) 'India's Agricultural Development Policy', Economic and Political Weekly 35.20: 1735-41 